\title{
Ecosystem services approach for water framework directive implementation
}

\author{
P. Blancher ${ }^{1}$, C. Vignon ${ }^{1}$, E. Catalon ${ }^{1}$, B. Maresca ${ }^{2}$, A. Dujin ${ }^{2}$, \\ X. Mordet ${ }^{2}$, I. Borowski ${ }^{3}$, L. Neubauer ${ }^{3}$, S. Rotter ${ }^{3}$, E. Interwies ${ }^{4}$, \\ M. C. Cunha ${ }^{5}$, J. C. Marques ${ }^{5}$, R. Pinto ${ }^{5} \&$ C. Palma \\ ${ }^{1}$ ASCONIT, France \\ ${ }^{2}$ CREDOC, France \\ ${ }^{3}$ seeconsult, Germany \\ ${ }^{4}$ InterSus, Germany \\ ${ }^{5}$ IMAR, Portugal
}

\begin{abstract}
The modern concept of 'ecosystem services' has progressed significantly in recent decades. Conceived primarily as a communication tool in the late 1970s to explain societal dependence on nature, it now incorporates economic dimensions and provides help to decision makers for implementing effective conservation policies which support human wellbeing and sustainable development. The founding work appeared in the late 1980s led to the conducting by policymakers of a more systematic assessment of the net monetary value associated with the preservation or restoration of natural areas. Following this work, many case studies have highlighted that ignorance of the value of natural capital into decisions on land use and resources allocation most likely results in degradation and destruction of this natural capital and eventually prove very costly for society. In this paper is presented a research project that investigates the methodological links of the two concepts (Ecosystems Services Approach (ESA) and Water Framework Directive (WFD) - economics). Its main academic innovation will be on assessing the potential "added value" of using the ESA approach and results in Integrated Water Resource Management policies decision and implementation processes, and the related communication and stakeholders' participation, with a specific focus to WFD.
\end{abstract}

Keywords: ecosystems services, WFD-economics. 


\section{Introduction}

ESAWADI (Utilising the Ecosystem Services Approach for Water Framework Directive Implementation) aims to analyze and provide advice on the potential usefulness of the ecosystem services approach (ESA) to support the implementation of the European Water Framework Directive (WFD) and in particular its economic requirements [2, 3]. It is funded through the second call for research proposals of the IWRM-Net initiative. The project started on 1st July 2010 and will last until 31 December 2012 (2 years and 6 months).

The project will work on linking the economic elements and requirements of the WFD and the current "state-of-the-art" regarding the assessment of ecosystem services. Through this project, the methodological links of the two concepts (ESA and WFD-economics) will be investigated and better understood. Its main academic innovation will be on assessing the potential "added value" of using the ESA approach and results in Integrated Water Resource Management policies decision and implementation processes, and the related communication and stakeholders' participation, with a specific focus to WFD. A website was set-up for the project and is accessible at: http://www.esawadi.eu.

The initial main research questions, as formulated in the proposal, are:

1. What are the differences and commonalities between ESA and WFDeconomic requirements? (as well as related background concepts, e.g. environmental and resource costs)

2. Can the existing literature and work so far on ESA provide additional knowledge in answering the key open questions regarding WFD-economics?

3. If so, what needs to be done (both methodologically and practically) in order to utilise ESA for WFD implementation?

4. Can ESA give a better illustration of the objectives of the WFD that is more understandable to stakeholders/the public?

5. Can ESA provide a good discussion basis for taking decisions related to WFD-implementation (selecting measures, assessing exemptions etc.)?

6. Can ESA assist water managers to assess environmental risks and prioritise implementation measures?

7. If so, what needs to be done in order to better utilize ESA for WFDimplementation?

\section{WFD current status and research questions}

\subsection{WFD main concepts and issues}

Overall, the WFD aims at achieving good water status for all waters by 2015 . It introduced a number of concepts and principles. In order to address the challenges in a co-operative and coordinated way, the Member States, Norway and the Commission agreed on a Common Implementation Strategy (CIS).

The central concept to the Water Framework Directive is the concept of integration that is seen as key to the management of water protection within the river basin district: 
- Integration of environmental objectives, combining quality, ecological and quantity objectives for protecting highly valuable aquatic ecosystems and ensuring a general good status of other waters;

- Integration of all water resources, combining fresh surface water and groundwater bodies, wetlands, transitional and coastal water resources at the river basin scale;

- Integration of all water uses, functions, values and impacts into a common policy framework, i.e. investigating water for the environment, water for health and human consumption, water for economic sectors, transport, leisure, water as a social good, investigating both point-source and diffuse pollution, etc.;

- Integration of disciplines, analyses and expertise, combining hydrology, hydraulics, ecology, chemistry, soil sciences, technology engineering and economics to assess current pressures and impacts on water resources and identify measures for achieving the environmental objectives of the Directive in the most cost-effective manner;

- Integration of water legislation into a common and coherent framework. The requirements of some old water legislation (e.g. the Fishwater Directive) have been reformulated in the Water Framework Directive to meet modern ecological thinking. After a transitional period, these old Directives will be repealed. Other pieces of legislation (e.g. the Nitrates Directive and the Urban Wastewater Treatment Directive) must be co-ordinated in river basin management plans where they form the basis of the programmes of measures;

- Integration of a wide range of measures, including pricing and economic and financial instruments, in a common management approach for achieving the environmental objectives of the Directive. Programmes of measures are defined in River Basin Management Plans developed for each river basin district;

- Integration of stakeholders and the civil society in decision-making, by promoting transparency and information to the public, and by offering a unique opportunity for involving stakeholders in the development of river basin management plans;

- Integration of different decision-making levels that influence water resources and water status, be local, regional or national, for an effective management of all waters; and

- Integration of water management from different Member States, for river basins shared by several countries, existing and/or future Member States of the European Union.

The high level of integration implies:

1. specific requirements in terms of determining good status

2. specific requirements in terms of undertaking economic analyses to inform the formulation, planning and evaluation of River Basin Management Plans

3. specific requirements in terms of participation and decision making processes [4]; and

4. specific methods for addressing the issue of scale especially when assessing ecosystem services or undertaking cost-effectiveness or other economic appraisals. In water management there are different scales at play: 
geographical (local landscape unit or ecosystem, river basin, regional, European, etc), administrative (municipalities, district, region and national authorities), and institutional scales (local water managers, regional and national water management authorities and ministries). These different levels do not necessarily tally together, when boundaries are not well defined or when multiple institutions overlap on a given ecosystem unit.

\subsection{Research needs: where are we right now?}

Although a lot of effort and work has been devoted to the WFD implementation, some key points still need attention and further research [5]:

- How to integrate the different biological, physico-chemical and hydromorphological elements status into a 'final' status classification?

- Metrics suggested in the WFD context consider mainly structural attributes of the system, missing the functional role of it. How can we add the concept of a healthy functioning ecosystem (e.g. [6]) to the assessment?

- How to include uncertainty estimations into the current assessment schemes [7]?

Under the survey conducted by the "Ad-hoc activity on water science policy interface", the main research needs identified, as far as ecological status is concerned [8], relates to:

- $\quad$ Developing and validating new bioassessment tools;

- $\quad$ Refining the knowledge about pressure-impacts relationships;

- $\quad$ Evolving towards a more functional and holistic approach of aquatic ecosystems;

- $\quad$ Reconnecting the socio-economical and biological issues.

- $\quad$ Reinforcing the knowledge on relationships between Good Ecological Status (GES), biodiversity and ecosystem services, with the developments below "An underlying assumption of WFD is that restoring or maintaining the good status will benefit to biodiversity. This hypothesis has not been explicitly tested. It is urgent to examine what links between good ecological status and biodiversity really are, for the different facets of biodiversity (taxonomy, functionalities, genetic aspects). A better understanding of these links have strong implications for governance at a European level and socio-economical issues related to biodiversity conservation ("Millennium Ecosystem Assessment"). Moreover, the scientific understanding of relations between society and aquatic system policies shall be improved.

Interdisciplinary programs with biologists, economists and sociologists need to be developed because ecosystem's health provides society with multiple ecological services, among which economical assets and social well-being. This approach would then provide a broader understanding of the GES in particular how it could be ensured with regards to socio-economical benefits". 


\section{Ecosystem services approach}

\subsection{Background and current developments}

The modern concept of 'ecosystem services' has progressed significantly in recent decades. Gómez-Baggethun et al. [9] conceived primarily as a communication tool in the late 1970s to explain societal dependence on nature, it now incorporates economic dimensions and provides help to decision makers for implementing effective conservation policies which support human wellbeing and sustainable development.

The founding work conducted by Costanza and Daly [10] in the late 1980s was the first attempt to conduct a large scale valuation of ecosystem services. It led to the conducting by policymakers of a more systematic assessment of the net monetary value associated with the preservation or restoration of natural areas. Following Costanza and Daly's work, many case studies have highlighted that ignorance of the value of natural capital into decisions on land use and resources allocation most likely results in degradation and destruction of this natural capital and eventually proves very costly for society.

On June 5th, 2001, Kofi Annan, Secretary General of the United Nations, launched the Millennium Ecosystem Assessment (MEA), the first world implementation programme of the Ecosystem Services Approach (ESA). The objective of the MEA was to widen the use of ESA and to highlight, at different territorial scales, the importance of ecosystems and biodiversity protection to maintain economic activity and wellbeing. It aimed at providing strong scientific understanding for how ecosystems affect human welfare and how they can be sustainably managed

The methodology consisted, firstly, in identifying services rendered by ecosystems, and second in quantifying those ecosystem services in order to assess their contribution to human well-being. Such an approach justifies the protection of ecosystems as it responds to the needs of the human being and its future generations. It assumes that quantifying ecosystem services and their contribution to welfare will eventually lead public and private decision-makers to consider their protection when setting policy and action priorities. One can therefore consider the MEA as an anthropocentric approach to the protection of biodiversity [11]. The Millennium Ecosystem Assessment is a milestone in the dissemination of the ecosystem services approach insofar as it proposes a methodology for assessing ecosystem services, and a preliminary identification and quantification of ecosystem services at a global scale from expert statements and existing figures. Despite the limitations of the exercise and the difficulties encountered in integrating the knowledge of ecologists, ecosystem approaches have significant popularity and is increasingly being applied, especially in developing countries.

Several countries have conducted national versions of the MEA, with members from ESAWADI team contributing to these evaluations: CREDOC and Asconit for France [12], IMAR for Portugal [13]. 
Research into ecosystem services has flourished considerably since the publication of the MEA, notably The Economics of Ecosystems and Biodiversity (TEEB) project which is making a compelling case for promoting conservation, by estimating the economic benefits of ecosystems to human welfare and the economic cost to society of ecosystem decline.

The ecosystem services approach is used quite widely when talking about biodiversity, but regarding water this is happening only slowly (mainly in the US, but very little in Europe, and almost not at all so far regarding the implementation of WFD-economic requirements). Nevertheless, related ecosystem services concepts have already been used on several occasions.

\subsection{Concepts and tools}

\subsubsection{The millennium ecosystem approach}

The ecosystem services approach adopted by the Millennium Ecosystem Assessment (MEA) examined how changes in ecosystem services influence human well-being. Human well-being is assumed to have multiple constituents, including the basic material for a good life, such as secure and adequate livelihoods, enough food at all times, shelter, clothing, and access to goods; health, including feeling well and having a healthy physical environment, such as clean air and access to clean water; good social relations, including social cohesion, mutual respect, and the ability to help others; security, including secure access to natural and other resources, personal safety, and security from natural and human-made disasters; and freedom of choice and action.

Even though the conceptual framework for the MEA makes a distinction between men and society on one side and ecosystems on the other, it assumes that people are integral parts of ecosystems and that a dynamic interaction exists between them and other parts of ecosystems, with the changing human condition driving, both directly and indirectly, changes in ecosystems and thereby causing changes in human well-being. At the same time, social, economic, and cultural factors unrelated to ecosystems alter the human condition, and many natural forces influence ecosystems.

Therefore, it is necessary to identify all ecosystem costs and benefits in relation to different human activities in order to protect and conserve the systems biodiversity and its sustainable use. This may be achieved through the identification of the impacts of human activities and through the quantification of their consequences on ecosystem services supply. This includes not only the ecosystem services that have a market price (e.g. agriculture products), but also services that have currently no market prices (e.g. disturbance regulation). Figure 1 illustrates the conceptual framework of the MEA.

\subsubsection{MEA classification of ecosystem services}

The MEA defined 4 main categories of ecosystem services (Figure 2):

1. Provisioning services, which are the provisioning of goods by ecosystems (food, fresh water, genetic resources...).

2. Regulating services, which are benefits resulting from regulation of ecosystem processes (climate regulation, disease regulation, pollination...). 


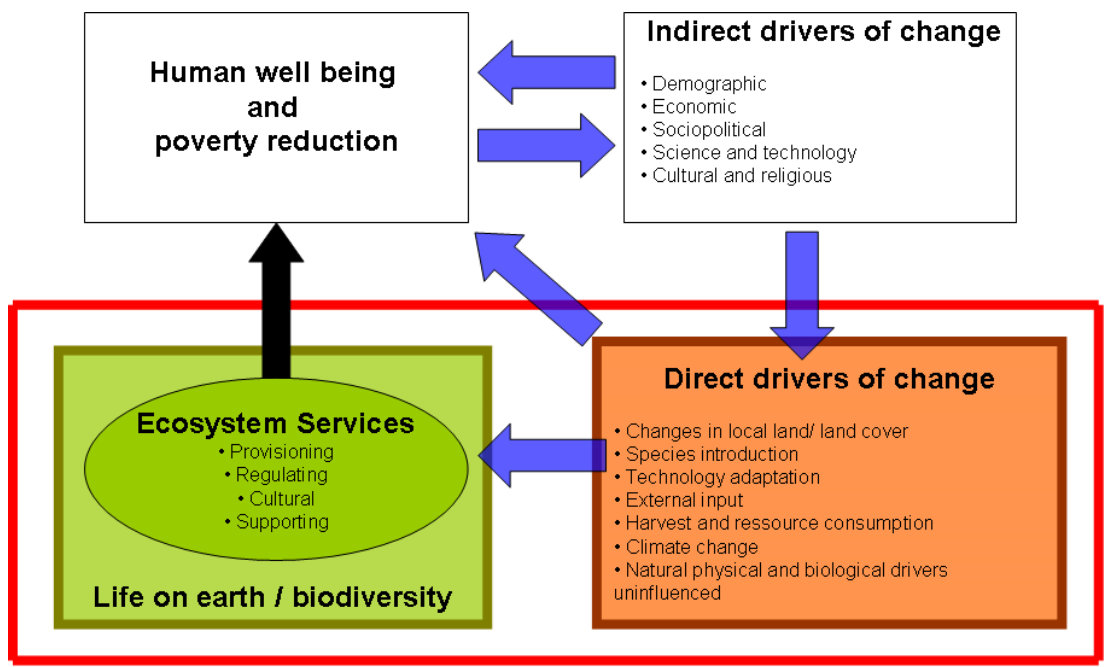

MEA(2003) Ecosystems and Human Well-Being. A Framework For Assessment

Figure 1: Logical framework of the millennium ecosystem assessment.

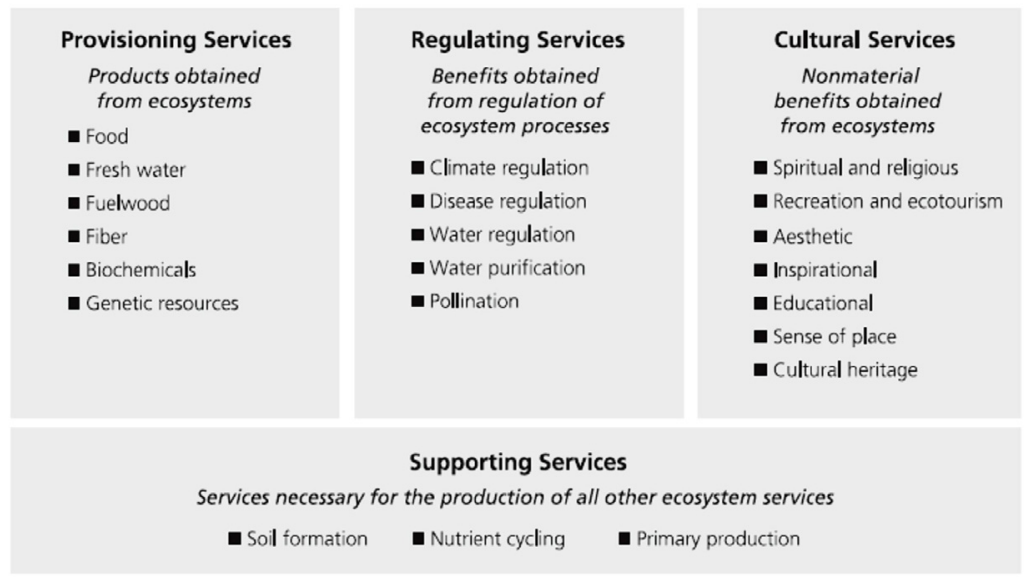

Figure 2: $\quad$ Four main categories of ecosystem services in the global MEA [14].

3. Cultural services, which are non-material benefits (spiritual and religious, recreation and ecotourism, aesthetic, sense of place...), where we can find traditional existence/non-use values used in environmental economics.

4. Supporting services which are ecosystem services necessary for the production of all other ecosystem services (soil formation, nutrient cycling...). 


\subsubsection{The limits of MEA anthropogenic approach and the ESAWADI approach}

Although the MEA general framework is the most widely accepted approach, seen as a starting point to conduct further evaluations, there is no single agreed way of describing ecosystem services [15], with further expansions to the MEA framework being suggested (e.g. [16]).

Many ecosystem services approaches adopt a mere anthropogenic perspective, i.e. the link between the stocks of natural assets found on the systems are connected to the flow of services that provide benefits to human society. Prevalence is given to economic valuation methods, with a main focus on the exchange value of ecosystem services (based on the consumer preferences and the actual use of an ecosystem service). As a reaction, biologists and ecologists developed approaches which put the emphasis on the maintenance of the ecosystem per se [17]. However, a better consideration of biological and ecological dimension should not lead to minimize the social and political dimension of ESA, particularly if we want to use it in a public participation and decision-making process.

We consider that the Ecosystem Services Approach implies investigating the links between the ecological state of ecosystems, their ecological functions [18], ecosystem services they provide and the resulting benefits for society $[19,20]$. Through the integration of the ecosystem inherent processes and associated biodiversity, and its sustainable use, the ecosystem services approach focuses on conserving natural ecosystems for human well-being first and foremost; but it shouldn't restrict itself to direct and tangibles benefits. By assessing ecosystems inherent value for sustaining indirect and long-term benefits for man and society, an ecosystem services approach provides a much more comprehensive and sustainable vision.

The ESAWADI project adopts the following ideas (Figure 3 [21]):

- $\quad$ Ecosystem Services Approach implies investigating the links between the ecological state of ecosystems, their ecological functions, ecosystem services they provide and the resulting benefits for society.

- Ecosystem services refer to the human use of ecological functions and relate only to positive impacts of ecosystems on human wellbeing through the provision of goods and services (we do not consider "disservices").

We shall dissociate ecosystem functions, ecosystem services and social benefits, and try to explain the links between these.

- We shall not count as ecosystem services, services which have implied a modification of the physical environment or "artificialisation" and result from it, as the benefits are not based on the existence of natural ecosystems.

- We shall include potential ecosystem services, even if these services are currently not experienced by society, since they may allow us to assess the benefits from an ecological restoration. 


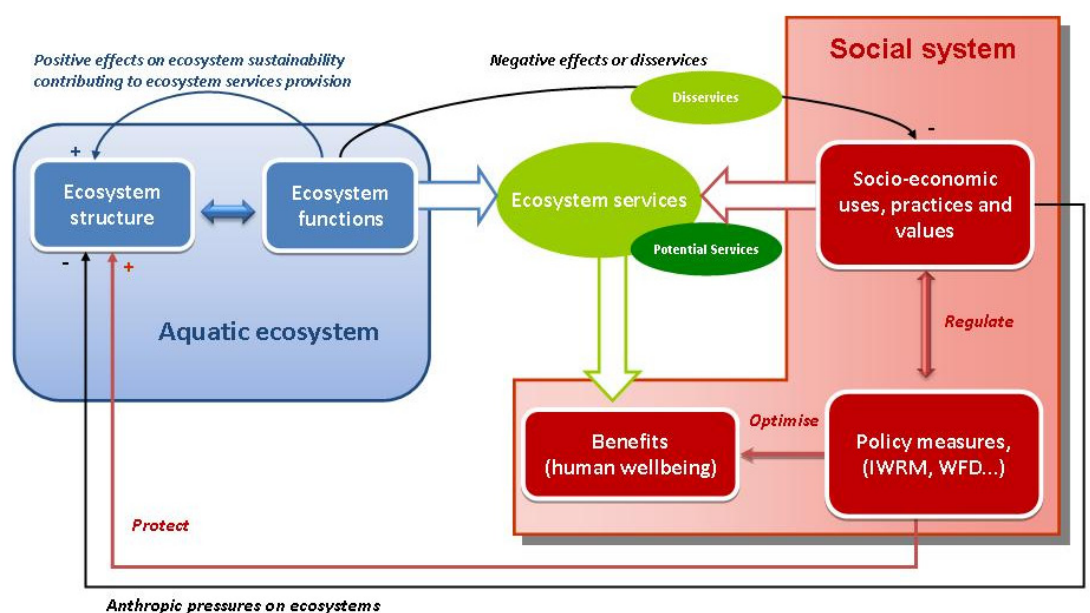

Figure 3: $\quad$ ESAWADI approach to ecosystem services.

\section{Conclusions}

An integrated water resources management policy, more specifically WFD, has to take into consideration interdependent ecosystems, supporting a variety of social uses and practices, regulated by different policies and institutions (regarding water, agriculture, land-use...).

ESAWADI will adopt a holistic ecosystem services approach where:

- $\quad$ the complex and systemic interactions between ecosystems and society are thoroughly described;

- the perspective is neither merely anthropocentric (focused on human benefits maximisation) nor ecosystem-centered (conservation without taking in consideration human needs), but oriented towards a sustainable co-evolution between nature and society. Conservation per se of ecosystems becomes an ESAWADI objective taking into consideration complex, yet not well understood, relations between ecosystem structure, functions and services, as well as human impacts. We consider that this is the basic underlying perspective of WFD with its ambitious goals regarding Good Ecological Status.

\section{References}

[1] EC., 2000. Directive of the European Parliament and of the Council 2000/60/EC establishing a framework for community action in the field of water policy PE-CONS 3639/1/00, 72 pp.

[2] WATECO, 2002. Common Implementation Strategy for the Water Framework Directive (2000/60/EC): Economics and the environment - The implementation challenge of the Water Framework Directive, Working Group 2.6 on Economic Analysis (WATECO), European Commission. 
[3] EFTEC, 2010. Scoping Study on the Economic (or Non-Market) Valuation Issues and the Implementation of the Water Framework Directive, report ENV.D.1/ETU/2009/0102rI for the European Commission DirectorateGeneral Environment.

[4] Mostert, E. (editor), Junier, S., Ridder, D., Interwies, E., Bouleau, G., Bots, P., Maurel, P., Richard, A., Abrami, G., Cernesson, F. and S. Richard (2009): Research Report No 1. Innovative Instruments and Institutions in Implementing the Water Framework Directive: i-five inception report. verfügbar unter www.i-five.org.

[5] Junier, S.; Borowski, I.; Bouleau, G.; Interwies; E. Mostert, E., 2011. Implementing the Water Framework Directive: lessons for the second planning cycle, in The Water Framework Directive: Action Programmes and Adaptation To Climate Change, P. Quevauviller, et al., Editors. 2011, RSC Publishing: Cambridge.

[6] de Jonge, V.N., Elliott, M., Brauer, V.S., 2006. Marine monitoring: its shortcomings and mismatch with the EU Water Framework Directive's objectives. Marine Pollution Bulletin 53: 5-19.

[7] Hering, D., Borja, A., Carstensen, J., Carvalho, L., Elliott, M., Feld, C.K., Heiskanen, A.S., Johnson, R.K., Moe, J., Pont, D., Solheim, A.L., van de Bund, W., 2010. The European Water Framework Directive at the age of 10: A critical review of the achievements with recommendations for the future. Science of the Total Environment 408: 4007-4019.

[8] CIS WFD - SPI (Common Implementation Strategy of the Water Framework Directive - Science Policy Interface), 2010, Report of the "Water Science meets Policy" Event, 30 September 2010, Brussels, EU RD Research, ONEMA, $70 \mathrm{p}$.

[9] Gómez-Baggethun, E., de Groot, R., Lomas, P., Montes, C., 2010. The history of ecosystem services in economic theory and practice: From early notions to markets and payment schemes. Ecological Economics 69: 12091218.

[10] Costanza, R. \& HE. Daly, 1987 "Toward an ecological economics" Ecological Modelling, vol. 38, September; R. Costanza et al., "The Value of the World's Ecosystem Services and Natural Capital," Nature Vol. 387 (1997).

[11] Blandin, P., 2009.- De la protection de la nature au pilotage de la biodiversité. Editions Quæ, Versailles : 122 p. (bl 211).

[12] CREDOC, Biotope, Asconit Consultants (2009), Etude exploratoire pour une évaluation des services rendus par les écosystèmes en France Application du Millennium Ecosystem Assessment à la France, étude conduite à la demande du Ministère de l'Ecologie, de l'Energie, du développement durable et de la Mer, www.developpementdurable.gouv.fr/IMG/pdf/Synthese_Rapport.pdf

[13] Pereira, H.M, T. Domingos, and L. Vicente (editors) (2004), Portugal Millennium Ecosystem Assessment: State of the Assessment Report, Centro de Biologia Ambiental, Faculdade de Ciências da Universidade de Lisboa. 
[14] Millennium Ecosystem Assessment, (2005), Ecosystems and Human well being, Global Assessment Reports, Vol.1: Current State and Trends (en ligne: http://www.millenniumassessment.org/en/Condition.aspx).

[15] Atkins, J.P., Burdon, D., 2006. An initial economic evaluation of water quality improvements in the Randers Fjord, Denmark, Mar. Poll. Bull. 53, 195-204.

[16] Beaumont N., Townsend, M., Mangi, S., Austin, M., 2006, Marine Biodiversitu - An Economic Evaluation: Building the evidence Base for the Marine Bill. Prepared for DEFRA, UK Plymouth Marine laboratory, UK, Plymouth.

[17] Marques JC, Basset A, Brey T, Elliott M., 2009, "The ecological sustainability trigon--a proposed conceptual framework for creating and testing management scenarios", Marine Pollution Bull., 2009 Dec, 58(12):1773-9.

[18] Bouvron M., Hernandez S. (D4E/MEDAD), Couvet D. (MNHN), 2008, Projet d'évaluation des fonctions écologiques des milieux en France, Collection Études et synthèses, Direction des Études Économiques et de l'Évaluation Environnementale (D4E), ministère de l'Ecologie, $93 \mathrm{p}$.

[19] O'Gorman, S. and Bann, C. (2008), A Valuation of England's Terrestrial Ecosystem Services, a report to Defra.

[20] Pinto R. et al (2010), Assessing estuarian quality under the ecosystem services scope: Ecological and socioeconomic aspects. Ecol. Complex, doi:10.1016/j.ecocom.2010.05.001.

[21] Blancher, P.; Vignon, C.; Catalon, E.; Maresca, B.; Dujin, A.; Mordet, X.; Borowski, I.; Neubauer, L.; Rotter, S.; Interwies, E.; Cunha, M.C.; Marques, J.C.; Pinto, R.; Palma, C. (2011), ESAWADI - Framework of Analysis, $82 \mathrm{p}$. 